\title{
DIAMETER DISTRIBUTION OF WOOD RESIDUES IN LOGGED AND UNLOGGED FOREST AREAS OF THE EASTERN BRAZILIAN AMAZON
}

\author{
Deusdedith Cruz Filho ${ }^{1 *}$, Paulo Luiz Contente de Barros ${ }^{1}$, José Natalino Macedo Silva ${ }^{1}$
}

*Corresponding author: deusdedith.filho@ufra.edu.br

\begin{abstract}
This study aimed to investigate the patterns of diameter distribution of residual wood pieces found on the forest ground (e.g. tree branches, sound and hollowed trunks, log trimmings) of an unlogged and of a logged forest area one year after logging operations with impact reduction techniques (EIR), by setting up a mathematical model. Diameters were field measured of wood residue pieces in 48 sampling units systematically distributed across the experimental area, 24 units for each situation, that is, unlogged (FNE) and logged forest (FE), with sampling errors of $8.32 \%$ and $7.58 \%$ respectively for the variable volume $\left(\mathrm{m}^{3}\right.$. ha $\left.{ }^{-1}\right)$, applying the line intercept sampling method proposed by Wagner (1968). In both situations, the diameter distribution of the wood residue pieces was decreasing and reverse J-shaped, similarly to the DBH distribution occurring in native forests of the Amazon. A highly significant linear correlation exists between the diameter class midpoints and the number of wood residue pieces. Distributions were modeled using the exponential equation proposed by Meyer (1952), whose adjusted coefficients of determination ( $\mathrm{r}^{2} \mathrm{aj}$.) were $98.6 \%$ and $94.8 \%$, for unlogged and logged forest areas respectively.
\end{abstract}

Key words: Line intercept sampling, rain forest, regression analysis, Amazon.

\section{DISTRIBUIÇÃO DIAMÉTRICA DE RESÍDUOS LENHOSOS, EM FLORESTA EXPLORADA E NÃO EXPLORADA NA AMAZÔNIA ORIENTAL BRASILEIRA}

RESUMO: Neste trabalho, objetivou-se estudar o comportamento da distribuição dos diâmetros das peças de resíduos lenhosos encontrados no chão da floresta (e.g galhos de árvores, troncos sãos e ocados, aparas de toras) em área de floresta explorada e em área com um ano após a exploração florestal, utilizando-se técnicas de redução de impactos (EIR), ajustando-se um modelo matemático. Os diâmetros das peças de resíduos foram coletados no campo mediante o levantamento de 48 unidades de amostra, distribuidas, sistematicamente, na área, sendo 24 unidades em cada situação de floresta não explorada (FNE) e floresta explorada (FE), com erro de amostragem para a variável volume $\left(\mathrm{m}^{3} \cdot \mathrm{ha}^{-1}\right)$ de $8,32 \%$ e 7,58 \% respectivamente, aplicando-se o método de amostragem por linhas interceptadoras (Line Intercept Sampling), proposto por Wagner (1968). A distribuição dos diâmetros dessas peças de resíduos encontrada nas duas situações levantadas foi decrescente e em forma de " $J$ " invertido, semelhante à distribuição dos DAP das árvores em florestas nativas da Amazônia. Existe correlação linear altamente significativa entre os centros de classe e o número de peças de residuos, sendo essas ajustadas pelo modelo exponencial proposto por Meyer (1952), cujos coeficientes de determinação ajustado ( $r^{2}$ aj.) encontrados foram de 98,6\% e 94,8\%, para floresta não explorada e floresta explorada, respectivamente.

Palavras-chave: Amostragem por linha interceptadora, floresta tropical, análise de regressão, Amazônia.

\section{INTRODUCTION}

Studies available in literature about diameter distribution in rain forests refer almost exclusively to diameter $(\mathrm{DBH})$ of standing trees. Authors are unanimous in referring to such distribution as being decreasing or reverse J-shaped (AZEVEDO, 1993; AZEVEDO et al., 2007; BARROS, 1980; FREITAS; HIGUCHI, 1993; PULZ et al., 1999; TEIXEIRA et al., 2007; VASCONCELOS et al., 2009).

Some authors, including Meyer et al. (1961), argue that tree diameter distribution could help evaluate the balance between mortality and recruitment. Barros (1980) described the diameter distribution of a dense forest tree population in the Tapajós region (Brazilian Amazon) and of some species individually. Pulz et al. (1999) referred to forest planning and also to harvest cycles based on diameter distribution data of the relevant tree population. Paula et al. (2004), again based on diameter distribution, categorized arboreal vegetation into ecological groups and characterized the successional stage of a stand in a forest stretch known as Mata da Biologia, in the Federal University of Viçosa. Silva Júnior (2005) applied diameter distribution to studies on floristics, phytosociology and structure of riparian forests in central Brazil, among other studies. Research studies exploring wood residues and relevant diameter distribution are yet scarce and deficient in Brazil and more specifically in the Amazon region (CRUZ FILHO; SILVA, 2009).

${ }^{1}$ Universidade Federal Rural da Amazônia - Belém, Pará, Brazil

Cerne, Lavras, v. 19, n. 3, p. 383-389, jul./set. 2013 
The findings in this work can potentially contribute to studies about nutrient cycling in forest environments, to estimates of aboveground carbon stock and woody material for use applications such as fuel for steelworks, raw material for woodworking parts, crafts or artistic pieces, among other applications.

Therefore, by using the line intercept sampling method proposed by Wagner (1968), this study aimed to estimate the diameter distribution of wood residues (RL) in a dense ombrophilous forest located in the eastern Brazilian Amazon, before and after forest logging operations.

\section{MATERIAL AND METHODS}

\subsection{Study site}

The experiment was conducted in a Forest Management Area (AMF) situated in the rural estate Fazenda Santa Marta, in the municipality of Moju, Pará ( $3^{\circ} 04^{\prime} \mathrm{S}$ and $49^{\circ} 14^{\prime} \mathrm{W}$ ). The local climate, according to Köppen classification, is Am type. Average annual rainfall is typically above $2,000 \mathrm{~mm}$, relative humidity is always high, $80 \%$ on average, and average monthly temperatures vary little throughout the year, $25^{\circ} \mathrm{C}$ on average.

The local geomorphology is known as Southern Amazon Depressions and Southern Amazon Residual Plateaus (INSTITUTO BRASILEIRO DE GEOGRAFIA E ESTATÍSTICA - IBGE, 1990), and local soils include red-yellow podzolic soil, red yellow latosol, yellow latosol, litholic soils and hydromorphic laterite.

The study site lies in the land area drained by Moju river, which is where a Sustainable Forest Management Plan (PMFS) is currently being conducted by Juruá Florestal enterprise. The phytoecological environment from which data was collected is known as dense ombrophilous forest, a forest type characterized by closed canopy, high biomass and some emergent trees with heights ranging from 30-50 meters (IBGE, 1990).

\subsection{Data collection and analysis}

The site from which data was collected is 426 ha in total area. Using impact reduction techniques, 217 ha were logged (FE), while the remaining 209 ha remained unlogged (FNE). Twenty-four sampling units were systematically distributed across each area, according to the sampling method proposed by Wagner (1968) and known as line intercept sampling, with transects being $250 \mathrm{~m}$ in length, to a total of 6,000 meters in each study situation.

Cerne, Lavras, v. 19, n. 3, p. 383-389, jul./set. 2013
This method consists in defining sampling units through L-length line segments. Diameters were measured of all pieces at the point where the transects intersected them, that way deriving a sample of wood residue pieces (RL) for the relevant population. In this study, wood residues are defined as being dead woody material fallen on the forest ground and at least $10 \mathrm{~cm}$ in diameter.

All sampling transects were oriented along the north-south direction, spaced $300 \mathrm{~m}$ apart and established from a randomly selected starting point. A record was kept of wood residue pieces (RL) resulting from all types of disturbance from forestry operations (intense and sparse logging sites, margin of internal roads, skidding trails, log stockyards and surrounding areas).

In the logged forest area (FE), data collection was performed around a year after logging was completed.

The most common application of this method has been for estimating total volume per hectare of dead wood residue, based on diameter measurements at the point where wood residue pieces are intersected by the sampling transects (MARSHALL et al., 2003), as is the case in this study.

For the variable volume per hectare $\left(\mathrm{m}^{3} \cdot \mathrm{ha}^{-1}\right)$, obtained for 24 sampling units, the sampling error was calculated according to the systematic sampling procedure used for each of the two study situations (SANQUETA et al., 2006).

For the logged area (FE) the sampling error was $7.58 \%$, while for the unlogged area (FNE) the sampling error was $8.32 \%$, both at the $5 \%$ significance level. Error results were considered accurate in this specific case (CRUZ FILHO; SILVA, 2009).

\subsection{Evaluation parameters and data analysis}

The diameter distribution of the wood residue pieces was categorized into class intervals of $10 \mathrm{~cm}$. The Pearson's coefficient ( $r$ ) was calculated to determine the linear correlation between class midpoint diameters and the respective number of wood residue pieces. A significant correlation was found between class midpoints and respective frequencies, and so a model was developed to explain such correlation by using the exponential equation of Meyer (MEYER, 1952):

$$
\mathrm{Np}_{\mathrm{i}}=\beta_{0} *(10)^{\beta_{1} \mathrm{Dp}} * \varepsilon_{\mathrm{i}}
$$

The model was linearized and the following was obtained: 
$\operatorname{logNp_{i}}=\log \beta_{0}+\beta_{1} \mathrm{Dp}_{\mathrm{i}}+\log \varepsilon_{\mathrm{i}}$

where

$\mathrm{Np}_{\mathrm{i}}=$ number of wood residue pieces sampled;

$\mathrm{Dp}_{\mathrm{i}}=$ diameter class midpoint of the wood residue pieces;

$\beta_{0}, \beta_{1}=$ model parameters;

$\log =$ decimal logarithm;

$\varepsilon_{\mathrm{i},}=$ random component.

This model was used because it fits well to decreasing distributions, which is suitable for modeling diameter distribution in rain forests. This distribution is referred to as 'negative exponential' as it generates a decreasing regression line, indicating that with the increasing diameter class of residue pieces, their occurrence decreases in each respective class.

With sampling errors of $8.32 \%$ and $7.58 \%$ obtained during field data collection, respectively for unlogged (FNE) and logged (FE) forest areas, the model was tested for fitting accuracy through calculations of F-test, estimated coefficient of determination $\left(\mathrm{r}^{2}\right)$, coefficient of variation $(\mathrm{CV} \%)$, error of the regression estimate (Sy.x), and tested also for fitting quality through graphical analysis of residuals and the mean percentage deviation (DMP \%) (CAMPOS; LEITE, 2006).

\section{RESULTS AND DISCUSSION}

\subsection{Unlogged forest (FNE)}

3.1.1 Distribution of wood residue pieces per diameter class

Diameter classes were defined at intervals of $10 \mathrm{~cm}$ and starting from a minimum diameter of $10 \mathrm{~cm}$, up to a maximum diameter of $90 \mathrm{~cm}$, to a total of eight classes.

Table 1 illustrates the distribution of number of wood residue pieces across different diameter classes, as well as the relative frequency and cumulative relative frequency.

The distribution of wood residue pieces was concentrated in the first diameter class, where the number of pieces found accounts for nearly $60 \%$ of the total, according to Table 1 . The number of pieces found in the first $(10-20 \mathrm{~cm})$ and second $(10-30 \mathrm{~cm})$ classes combined account for around $81 \%$ of the total found, while residue pieces $30 \mathrm{~cm}$ or more in diameter only account for $18.7 \%$ of the total found in the field survey.

The fact that residue pieces found on forest ground were concentrated in the first diameter class $(10-20 \mathrm{~cm})$ is due to the occurrence of canopy elements such as branches
Table 1 - Distribution of the number of wood residue pieces across diameter classes, in unlogged forest (FNE).

Tabela 1 - Distribuição do número de peças RL, em classes de diâmetro para floresta não explorada (FNE).

\begin{tabular}{cccccc}
\hline $\begin{array}{c}\text { Class } \\
\text { number }\end{array}$ & $\begin{array}{c}\text { Class }^{1} \\
\mathrm{~cm}\end{array}$ & $\begin{array}{c}\text { Dpi } \\
\mathrm{cm}\end{array}$ & Npi & $\begin{array}{c}\text { Fr } \\
\%\end{array}$ & $\begin{array}{c}\text { Facum } \\
\%\end{array}$ \\
\hline 1 & $10-20$ & 15 & 408 & 59.65 & 59.65 \\
2 & $20-30$ & 25 & 148 & 21.64 & 81.29 \\
3 & $30-40$ & 35 & 72 & 10.53 & 91.81 \\
4 & $40-50$ & 45 & 26 & 3.80 & 95.61 \\
5 & $50-60$ & 55 & 16 & 2.34 & 97.95 \\
6 & $60-70$ & 65 & 9 & 1.32 & 99.27 \\
7 & $70-80$ & 75 & 4 & 0.58 & 99.85 \\
8 & $80-90$ & 85 & 1 & 0.15 & 100.00 \\
\hline & Total & - & 684 & 100.00 & - \\
\hline
\end{tabular}

${ }^{1}$ Diameter class of wood residue pieces, in centimeters;

$\mathrm{Dp}_{\mathrm{i}}=$ Class midpoint, diameter of pieces;

$\mathrm{Np}_{\mathrm{i}}=$ Number of wood residue pieces per diameter class $\mathrm{i}$;

$\mathrm{Fr}=$ Relative frequency, in \%;

Facum $=$ Cumulative relative frequency, in $\%$.

and limbs which come off the trees. In such context, the number of wood residue pieces with a diameter of $10 \mathrm{~cm}$ or slightly over was high. The number of wood residue pieces with a diameter of over $40 \mathrm{~cm}$ accounted for $10 \%$ of the total found. This percentage is similar to the frequency found in the $30-40 \mathrm{~cm}$ class $(10.53 \%)$. These results indicate a strong tendency of diameters to form a reverse J-shaped curve in graphical representation (Figure 1).

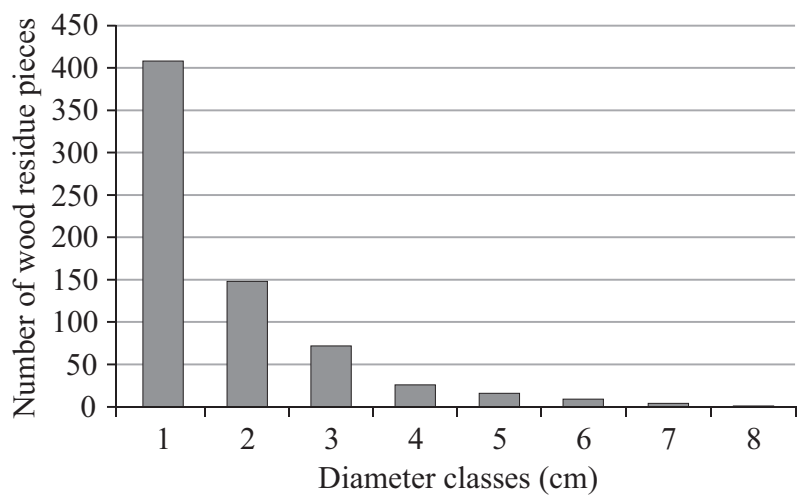

Figure 1 - Diameter distribution of wood residue pieces in unlogged forest.

Figura 1 - Distribuição de diâmetro dos RL em floresta não explorada.

Cerne, Lavras, v. 19, n. 3, p. 383-389, jul./set. 2013 
According to results, the diameter distribution of wood residue pieces across the forest ground tended to follow the same distribution pattern as standing trees in native forest stands, as seen in Figure 1.

3.1.2 Correlation between diameter classes and number of wood residue pieces in unlogged forest (FNE)

The degree of linear association between diameter class midpoints and the number of wood residue pieces of each class found on the ground of unlogged forest (FNE) was highly significant $(\mathrm{r}=0.9872 ; p<0.001)$. This indicates that both the branches fallen from standing trees and the residual tree pieces found on unlogged forest ground as a result of natural fall did cover the entire diameter range, that is, $10-90 \mathrm{~cm}$, noting that frequency decreased to the extent that diameters increased, as illustrated in Figure 1.

3.1.3 Fitting the exponential model of Meyer (1952) for unlogged forest

As a high degree of association was verified between number of residue pieces and relevant diameter class midpoints, the exponential model proposed by Meyer (1952) was then used to try and explain the correlation between these variables.

Based on field data accordingly grouped into classes, the following equation was derived to describe the diameter distribution of wood residue pieces found on the ground of unlogged forest area:

$$
\begin{aligned}
& \widehat{\operatorname{logNpi}}=3.08002-0.034566 * \mathrm{Dpi} \text { or } \\
& \widehat{\mathrm{Npi}}=1202.32 * 10^{\left(-0.034566^{*} \mathrm{Dpi}\right)}
\end{aligned}
$$

The model was tested for accuracy, which was verified by a highly significant $F$ value $(F=1077.65$; $\mathrm{p}<0.001)$, a low coefficient of variation $(\mathrm{CV}=7.1 \%)$, an estimate error of 0.0965 , an adjusted coefficient of determination $\left(\mathrm{r}^{2}{ }_{\text {aj }}\right.$ ) of $0.986 \%$, indicating that $98.6 \%$ of data variations are explained by the equation.

The model was also tested for fitting quality, which was verified by graphical analysis of the regression residuals and by the mean percentage deviation value which revealed an overestimation of $2.1 \%$, indicating no bias, as is illustrated by the distribution of positive and negative residuals in Figure 2.

A graphical representation of the distribution of wood residue pieces as a function of diameter classes, according to the exponential model of Meyer, is provided in Figure 3.

Cerne, Lavras, v. 19, n. 3, p. 383-389, jul./set. 2013

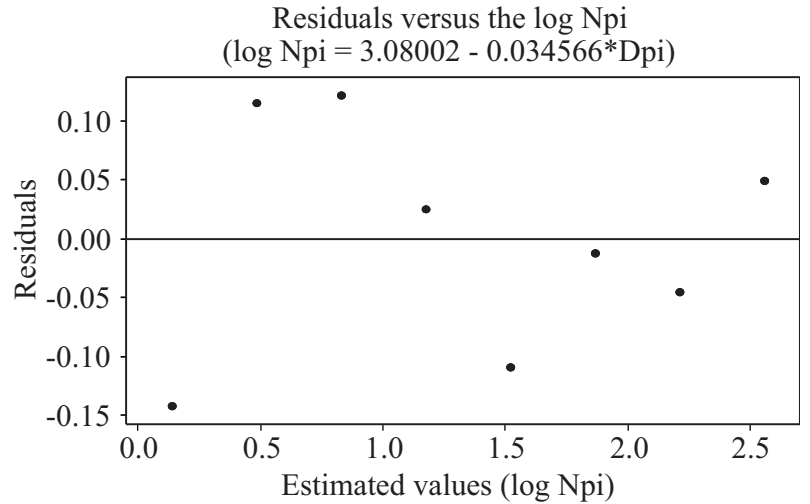

Figure 2 - Distribution of regression residuals as a function of the variable $\log (\widehat{\mathrm{Npi}})$, in unlogged forest.

Figura 2 - Distribuição dos resíduos da regressão em relação a variável log $(\widehat{\mathrm{Npi}})$ para a situação de floresta não explorada.

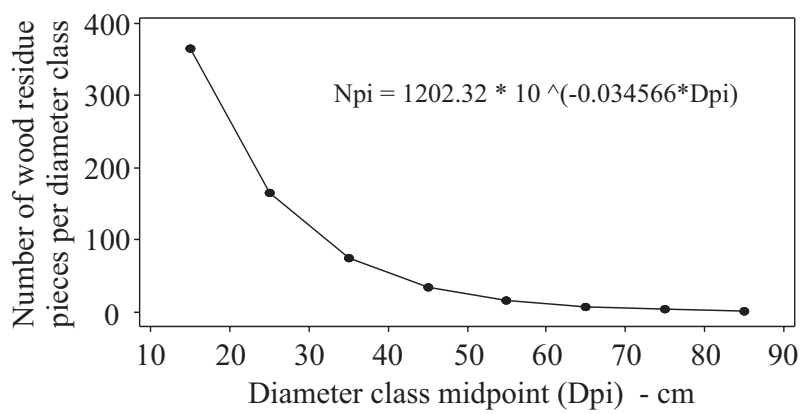

Figure 3 - Graphical representation of the distribution of wood residue pieces relative to diameter classes, according to the exponential equation of Meyer, in unlogged forest.

Figura 3 - Representação gráfica da distribuição das peças de $R L$ em relação às classes de diâmetro de acordo com a equação exponencial de Meyer, em floresta não explorada.

\subsection{Logged forest (FE)}

The diameter distribution of residue pieces was found to be concentrated in the first and second diameter classes, namely $10-20 \mathrm{~cm}$ and $20-30 \mathrm{~cm}$, which accounted for around $80 \%$ of the total. The diameter class $30-40$ $\mathrm{cm}$ accounted for around $10 \%$, while pieces found in the remaining classes, over $40 \mathrm{~cm}$ in diameter, accounted for around $8 \%$.

In the logged forest area, the distribution of wood residue pieces across diameter classes was similar to the pattern found in the unlogged area, which in turn followed the same decreasing DBH distribution pattern as standing trees in the dry upland forests of the Amazon, forming a 
reverse J-shaped curve. Pieces with a diameter less than $40 \mathrm{~cm}$ accounted for $92 \%$ and $91.56 \%$ of the total, in unlogged (FNE) and logged (FE) areas respectively. In both situations, the number of pieces $10-20 \mathrm{~cm}$ in diameter accounted for around $60 \%$, while pieces $20-30 \mathrm{~cm}$ in diameter accounted for around 20\%, and pieces $30-40 \mathrm{~cm}$ accounted for around $10.5 \%$ of the total (Table 3 and Figure 4).

Table 3 - Distribution of the number of wood residue pieces across diameter classes, in logged forest (EIR).

Tabela 3 - Distribuição do número de peças de RL em classes de diâmetro para floresta explorada (EIR).

\begin{tabular}{cccccc}
\hline $\begin{array}{c}\text { Class } \\
\text { number }\end{array}$ & $\begin{array}{c}\text { Class }^{1} \\
\mathrm{~cm}\end{array}$ & $\begin{array}{c}\text { Dpi } \\
\mathrm{cm}\end{array}$ & Npi & $\begin{array}{c}\text { Fr } \\
\%\end{array}$ & $\begin{array}{c}\text { Facum } \\
\%\end{array}$ \\
\hline 1 & $10-20$ & 15 & 663 & 60.8 & 60.8 \\
2 & $20-30$ & 25 & 222 & 20.3 & 81.1 \\
3 & $30-40$ & 35 & 114 & 10.4 & 91.6 \\
4 & $40-50$ & 45 & 49 & 4.5 & 96.1 \\
5 & $50-60$ & 55 & 28 & 2.6 & 98.6 \\
6 & $60-70$ & 65 & 7 & 0.6 & 99.3 \\
7 & $70-80$ & 75 & 3 & 0.3 & 99.5 \\
8 & $80-90$ & 85 & 2 & 0.2 & 99.7 \\
9 & $\geq 90$ & 95 & 3 & 0.3 & 100.0 \\
\hline & Total & & 1091 & 100.0 & - \\
\hline
\end{tabular}

${ }^{1}$ Diameter class of wood residue pieces, in centimeters; $\mathrm{Dp}_{\mathrm{i}}=$ Class midpoint, diameter of pieces;

$\mathrm{Np}_{\mathrm{i}}=$ Number of wood residue pieces per diameter class $\mathrm{i}$;

$\mathrm{Fr}=$ Relative frequency, in $\%$;

Facum $=$ Cumulative relative frequency, in $\%$.

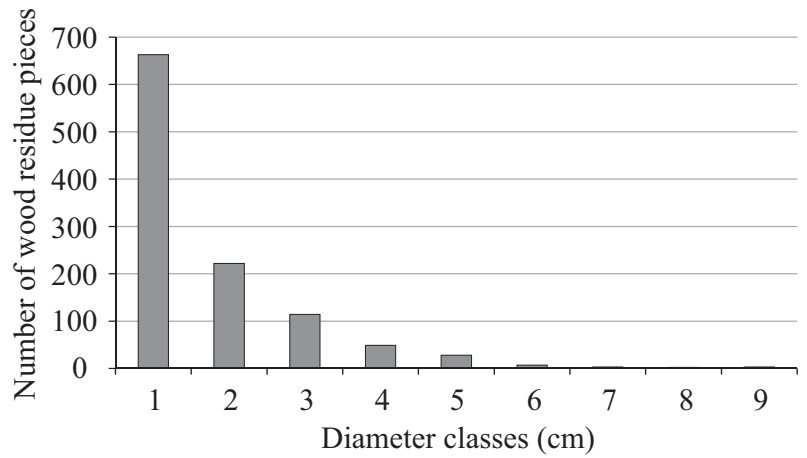

Figure 4 - Diameter distribution of wood residue pieces in logged forest (EIR).

Figura 4 - Distribuição de diâmetro dos RL em floresta explorada (EIR).
3.2.1 Correlation between diameter classes and number of wood residue pieces in logged forest (FE)

A correlation coefficient was calculated for the logged area $(r=0.977 ; p<0.01)$. Therefore, a highly significant correlation exists between the diameter classes and respective frequencies of residue pieces found on logged forest ground.

3.2.2 Fitting the exponential model of Meyer (1952) for logged forest

As a highly significant correlation was found, the exponential model proposed by Meyer (1952) was then used to try and explain such association.

The fitting result for diameter classes and respective frequencies, according to the proposed model, is as follows:

$$
\begin{aligned}
& \widehat{\operatorname{logNpi}}=3.1739-0.03253 * \text { Dpi or } \\
& \widehat{\mathrm{Npi}}=1492.451 * 10^{\left(-0.03253^{*} \text { Dpi }\right)}
\end{aligned}
$$

where

Npi $=$ Frequency of wood residue pieces;

$\mathrm{Dpi}=$ Diameter of wood residue pieces, in $\mathrm{cm}$.

The model was tested for accuracy, which was verified by a highly significant $F$ value $(F=147.23$; $\mathrm{p}<0.001)$, coefficient of variation $(\mathrm{CV}=15.0 \%)$, estimate error of 0.2076 , adjusted coefficient of determination $\left(\mathrm{r}_{\mathrm{aj}}^{2}\right)$ of 0.948 , indicating that $94.8 \%$ of data variations are explained by the equation.

The model was also tested for fitting quality, which was verified by graphical analysis of the regression residuals (Figure 5) and by the mean percentage deviation value which revealed an overestimation of $10.15 \%$. In contrast to the result found for unlogged forest, the value found here is much higher, due to the occurrence of residue pieces originated from sound or hollowed trunks, which increased the existing diameter variability to a point where some pieces reached well above $90 \mathrm{~cm}$. Other values, however, including CV\%, Sy.x and $\mathrm{r}^{2} \mathrm{aj}$., as well as the distribution of positive and negative residuals (Figure 5), indicate that the model is suitable for fitting the diameter distribution of wood residue pieces in the logged forest area.

In the case of the logged forest area, it was observed that the model proposed by Meyer (1952) had an acceptable fitting quality, with an overestimation of around $10 \%$ and no fitting bias, as is illustrated in Figure 5, and

Cerne, Lavras, v. 19, n. 3, p. 383-389, jul./set. 2013 


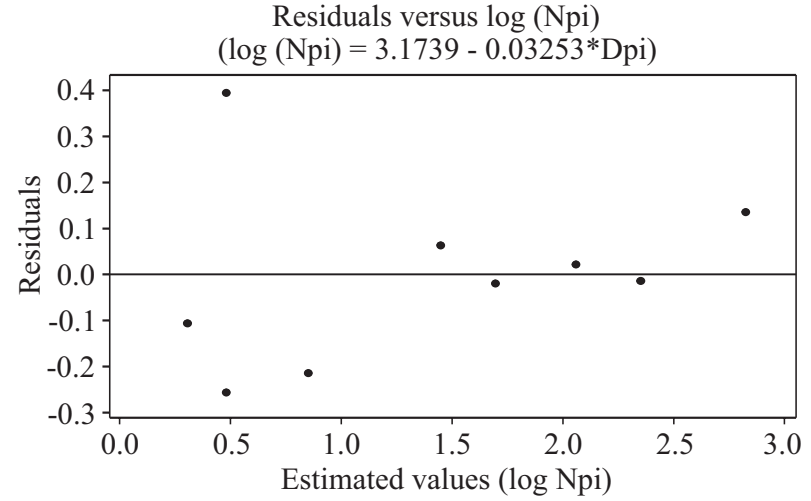

Figure 5 - Distribution of regression residuals as a function of the variable log (Npi), in logged forest (EIR).

Figura 5-Distribuição dos resíduos da regressão em relação a variável log (Npi) para a situação de floresta explorada (EIR).

with around $95 \%$ of the piece frequency being explained by diameter class midpoints. That said, the unlogged forest area had superior fitting quality in comparison with the logged forest area.

In the logged forest area, the wood residue pieces were distributed evenly along the curve, across the four smaller diameter classes (Figure 6). From the fifth class onward, whose midpoint is $55 \mathrm{~cm}$, a reduction was noted in the piece frequency. Few pieces were recorded in the larger diameter classes. The curve reveals that, where impact reduction techniques are adopted in forestry operations, the correlations of diameter classes with respective piece frequencies are similar to those found in unlogged forest, in terms of the trend of the regression curve. It is necessary to test the line intercept sampling methodology and the exponential model of Meyer (1952) in other forest exploration methods in order to verify suitability, given that this model was developed for forest stands and can be used for estimates of diameter distribution of wood residue pieces.

The result of applying the equation of Meyer (1952) for modeling diameter distribution in a forest area logged with impact reduction techniques revealed that the modeled number of residue pieces was similar to the observed frequency, except for the first class which had a large number of pieces. This is due to concentration of pieces less than $20 \mathrm{~cm}$ in diameter, particularly those fallen from the treetops, as well as to increased diameter variability from inclusion of large diameter pieces originated from log remainder after logging operations were completed.

Cerne, Lavras, v. 19, n. 3, p. 383-389, jul./set. 2013

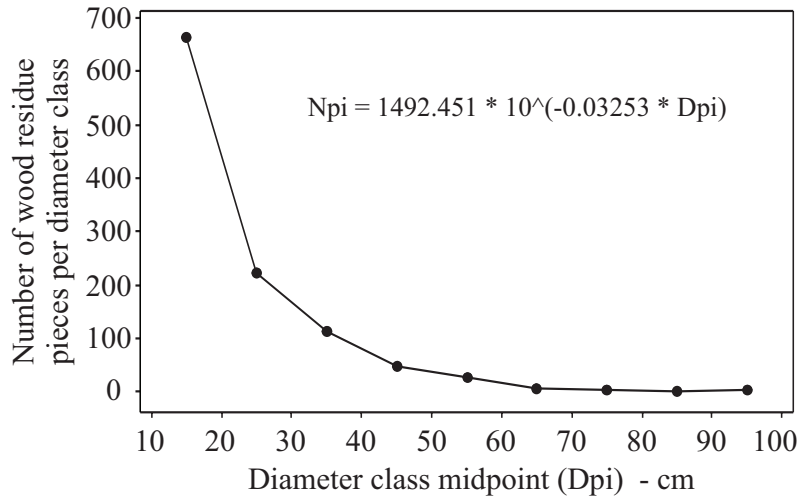

Figure 6 - Graphical representation of the distribution of wood residue pieces relative to diameter classes, according to the exponential equation of Meyer, in logged forest (EIR).

Figura 6-Representação gráfica da distribuição das peças de $R L$ em relação às classes de diâmetro de acordo com equação exponencial de Meyer, em floresta explorada (EIR).

\section{CONCLUSIONS}

The diameter frequency distribution of wood residue pieces (RL) was reverse J-shaped both in unlogged and in logged forest areas, similarly to the DBH distribution pattern found for standing trees in dry upland forests of the Amazon.

The negative exponential model proposed by Meyer (1952) fitted well to the diameter distribution of wood residue pieces found on the ground of both the unlogged and the logged forest areas.

The line intercept sampling method adopted in this study proved suitable to estimate the diameter distribution of wood residue pieces found on the ground of dry upland forests of the Amazon.

\section{REFERENCES}

\section{AZEVEDO, C. P. Predição da distribuição diamétrica} de povoamentos florestais ineqüiâneos pelo emprego da matriz de transição. 1993. 118 f. Dissertação (Mestrado em Engenharia Florestal) - Universidade Federal de Viçosa, Viçosa, 1993.

AZEVEDO, C. P. de; SANQUETTA, C. R.; SILVA, J. N. M.; MACHADO, S. A.; SOUZA, C. R. de; OLIVEIRA, M. M. de. Predição da distribuição diamétrica de uma floresta manejada experimentalmente através de um Sistema de Equações Diferenciais. Acta Amazônica, Manaus, v. 37, n. 4, p. 521532, 2007. 
BARROS, P. L. C. Estudo das distribuições diamétricas da floresta do Planalto Tapajós, Pará. 1980. 123 f. Dissertação (Mestrado em Ciências Florestais) - Universidade Federal do Paraná, Curitiba, 1980.

CAMPOS, J. C. C.; LEITE, H. G. Mensuração florestal: perguntas e respostas. 2. ed. Viçosa, MG: UFV, 2006. 470 p.

CRUZ FILHO, D.; SILVA, J. N. M. Avaliação da quantidade de resíduos lenhosos em floresta não explorada e explorada com técnicas de redução de impactos, utilizando amostragem por linha interceptadora, no médio rio Moju, Amazônia Oriental, Brasil. Acta Amazônica, Manaus, v. 39, n. 3, p. 527 532, 2009.

FREITAS, J. V.; HIGUCHI, N. Projeções da distribuição diamétrica de uma floresta tropical úmida de terra firme com a utilização da cadeia de Markov. In: CONGRESSO FLORESTAL PANAMERICANO, 1.; CONGRESSO FLORESTAL BRASILEIRO, 7., 1993, Curitiba. Anais... Curitiba: SBS/SBEF, 1993. p. 545-548.

INSTITUTO BRASILEIRO DE GEOGRAFIA E ESTATÍSTICA. Projeto zoneamento das potencialidades dos recursos naturais da Amazônia Legal. Rio de Janeiro, 1990. 212 p.

MARSHALL, P. L.; DAVIS, G.; TAYLOR, S. W. Using line intersect sampling for coarse woody debris: practitioners' questions addressed. Ottawa: Forest Service British Columbia, 2003. (Ecology, EN 012).

MEYER, H. A. Structure, growth, and drain in balanced uneven-aged forests. Journal of Forestry, Washington, v. 50, n. 2, p. 85-92, 1952.
MEYER, H. A.; RECKNAGEL, A. B.; STEVENSON, D. D. Forest management. New York: The Ronald Press, 1961. 282 p.

PAULA, A.; SILVA, A. F.; MARCO JÚNIOR, P.; SANTOS, F. A. M.; SOUZA, A. L. Sucessão ecológica da vegetação arbórea em uma Floresta Estacional Semidecidual. Acta Botânica Brasílica, Viçosa, v. 18, n. 3, p. 407-423, 2004.

PULZ, F. A.; SCOLFORO, J. R.; OLIVEIRA, A. D.; MELLO, J. M.; OLIVEIRA FILHO, A. T. Acuracidade da predição de distribuição diamétrica de uma floresta inequiânea com a matriz de transição. Cerne, Lavras, v. 5, n. 1, p. 1-14, 1999.

SANQUETA, C. R.; WATZLAWICK, L. F.; CÔRTE, P. D.; FERNANDES, L. A. V. Inventários florestais: planejamento e execução. Curitiba: Multi-Gráphic, 2006. 271 p.

SILVA JÚNIOR, M. C. da. Fitossociologia e estrutura diamétrica na mata de galeria do Pitoco, na Reserva Ecológica do IBGE, DF. Cerne, Lavras, v. 11, n. 2, p. 147-158, abr./jun. 2005.

VASCONCELOS, S. S.; HIGUCHI, N.; OLIVEIRA, M. V. N. Projeção da distribuição diamétrica de uma floresta explorada seletivamente na Amazônia Ocidental. Acta Amazônica, Manaus, v. 39, n. 1, p. 71-80, 2009.

TEIXEIRA, L. M.; CHAMBERS, J. Q.; SILVA, A. R.; LIMA, A. J. N.; CARNEIRO, V. M. C.; SANTOS, J. dos; HIGUCHI, N. Projeção da dinâmica da floresta natural de Terra-firme, região de Manaus-AM, com o uso da cadeia de transição probabilística de Markov. Acta Amazônica, Manaus, v. 37, n. 3, p. 377-384, 2007.

WAGNER, C. E. van. The line intercept method in forest fuel sampling. Forest Science, Washington, v. 14, p. 20-26, 1968.

Received: March 4, 2011; accepted: December 20, 2012.

Excerpt from a MSc Dissertation in Forest Sciences, Amazon Federal Rural University, 2005. Sponsored by the Amazon Development Agency and included in the Good Management Project/EMBRAPA

Cerne, Lavras, v. 19, n. 3, p. 383-389, jul./set. 2013 
